\title{
NTRK1 Gene Product
}

National Cancer Institute

\section{Source}

National Cancer Institute. NTRK1 Gene Product. NCI Thesaurus. Code C105367.

A protein encoded by the NTRK1 gene. 